\title{
Андрій Королько,
}

кандидат історичних наук, доцент кафедри історії України і методики викладання історії ДВНЗ «Прикарпатський національний університет імені Василя Стефаника» (м. Івано- Франківськ, Україна)

\section{Andrii Korolko,}

Vasyl Stefanyk Precarpathian National University (Ivano-Frankivsk, Ukraine)

andrii.korolko@pnu.edu.ua

ORCID ID 0000-0001-7435-5806

\section{Любов Прокопів,}

кандидат педагогічних наук, доцент кафедри педагогіки та освітнього менеджменту імені Богдана Ступарика, ДВНЗ «Прикарпатський національний університет імені Василя Стефаника»

(м. Івано-Франківськ, Україна)

\section{Liubov Prokopiv,}

$\mathrm{PhD}$ in Education, Associate Professor of the Department of Pedagogy and Educational Management after Bohdan Stuparyk Vasyl Stefanyk Precarpathian National University (Ivano-Frankivsk, Ukraine) liubov.prokopiv@pnu.edu.ua ORCID ID 0000-0001-8661-510X Researcher ID E-2262-2019

\section{Вікторія Кречко,}

магістрантка, ДВНЗ «Прикарпатський національний університет імені Василя Стефаника» (м.Івано-Франківськ, Україна)

\section{Viktoria Krecko,}

Undergraduate of Vasyl Stefanyk

Precarpathian National University

(Ivano-Frankivsk, Ukraine)

kreckoviktoria643@gmail.com

ORCID ID 0000-0003-2855-2694

УДК 378.146 : 371.3 :374.31 


\title{
ОСОБЛИВОСТІ ВПРОВАДЖЕННЯ МУЗЕЙНОЇ ПЕДАГОГІКИ В СУЧАСНОМУ ІННОВАЦІЙНОМУ ОСВІТНЬОМУ ПРОСТОРІ УКРАЇНИ (НА ПРИКЛАДІ МУЗЕЇВ МІСТА КОЛОМИЇ)
}

Анотація. У статті висвітлено особливості використання музейної педагогіки в контексті компетентнісного підходу (на прикладі музеїв м. Коломиї). Аргументовано, що музей виступає для особистості відкритим освітнім простором, територією, де не лише цікаво, а й повчально. Залучення до освітнього простору засобів музейної педагогіки сприяє вихованню свідомих громадян та патріотів своєї держави, ініціативних та вмотивованих людей, які в майбутньому сприятимуть збереженню власної національної ідентичності. У цьому контексті проблема $€$ актуальною для дослідження. Мета публікації - з'ясувати специфіку компетентнісних підходів до впровадження музейної педагогіки в сучасному інноваційному освітньому просторі України (на прикладі музеїв міста Коломиї).

У дослідженні використано як теоретичні методи, фокусовані інтерв'ю, так методи педагогічної реконструкції, оцінки сильних та слабких сторін роботи. Отримані результати підтвердили результативність обраних шляхів впровадження педагогіки партнерства в Карпатському освітньому просторі.

Ключові слова: музей, музейна педагогіка, інноваційні технології навчання і виховання у ЗВО, проект, інтерактивні технології.

\section{FEATURES OF IMPLEMENTATION OF MUSEUM PEDAGOGY IN THE MODERN INNOVATIVE EDUCATIONAL SPACE OF UKRAINE (ON THE EXAMPLE OF MUSEUMS OF KOLOMYIA)}

\begin{abstract}
The article presents the results of the study aimed at identifying the features and basic approaches to the introduction of museum pedagogy on the example of museums in Kolomyia. Using the competency-based approach, the authors specify the main approaches to the formation of museum pedagogy as an effective tool for preserving the Ukrainian material and spiritual heritage, including entrepreneurship. The study identified the effective aspects of the introduction of museum pedagogy in the Carpathian educational space based on awareness and cooperation that reflect the multifunctionality of all structures of influence and ensure the effectiveness of the educational space in general.

The study used theoretical methods, focused interviews as well as methods of pedagogical reconstruction, assessment of strengths and weaknesses of the work. Museum pedagogy promotes the implementation of patriotic, aesthetic, legal and moral education, which are provided by the Concept of the New Ukrainian School.

The obtained results of the research confirmed the effectiveness of the chosen ways of introduction of museum pedagogy in the Carpathian educational space. This allowed to significantly increase the levels of its manifestation, namely to replace traditional learning with individual, to use innovative and non-traditional learning technologies; implement competency-based, differentiated, personality-oriented, individual approaches, innovative learning technologies; plan subject-to-subject ways to get feedback; to promote universal human values.
\end{abstract}

Keywords: museum, museum pedagogy, innovative technologies of teaching and education in IHE, project, interactive technologies.

\section{ВСТуП}

Постановка проблеми. У реаліях сьогодення сучасна українська освіта перебуває в стані активного реформування, переорієнтації, впровадження новітніх освітніх технологій, які сприятимуть вихованню творчої, всебічно розвиненої особистості, яка наділена компетентностями (обізнаність, досвід. - авт.), якими можна сміливо оперувати в життєвих ситуаціях. Таким прагне виховати особистість сучасний освітній простір.

Новітні документи (Закон України «Про освіту», Концепція НУШ та ін.) наголошують, що сучасний випускник не тільки всебічна особистість, а й патріот своєї Батьківщини, свідомий громадянин своєї країни, який розуміє власну значущість в середовищі, де зростає (Закон України «Про освіту», 2017, с. 12).

Аналіз наукових досліджень і публікацій. У наукових дослідженнях М. Арсака, Т. Вайнберг, Л. Кречковського І. Самсакова та ін. докладно розкрито проблеми музейної педагогіки. М. Арсак є автором окремих невеликих статей про діяльність музеїв міста Коломиї, зокрема музею історії, у яких доступно висвітлює найважливіші аспекти діяльності музею (Арсак М., 2005). Т. Вайнберг акцентує увагу на те, що музейна педагогіка не має обмежень, отже, може використовуватися в різних навчальних предметах (Вайнберг Т., 2014, с. 2-7), І. Самсакова сфокусувала увагу на використанні в освітньому процесі засобів музейної педагогіки (Самсакова І., 2015, с. 119-123).

META I ЗАВДАННЯ ДОсЛІДЖЕННЯ - з'ясувати специфіку компетентнісних підходів до впровадження музейної педагогіки в сучасному інноваційному освітньому просторі України (на прикладі музеїв міста Коломиї).

\section{МЕТОДИ ДОСЛІДЖЕННЯ}

У роботі використано теоретичні методи, фокусовані інтерв'ю, методи педагогічної реконструкції, оцінки сильних та слабких сторін роботи, аналіз періодики австрійської доби архіву Національного музею народного мистецтва Гуцульщини та Покуття ім. Й. Кобринського (далі - НМНМГП імені Й. Кобринського) та ін.

\section{РЕЗУЛЬТАТИ ДОСЛІДЖЕННЯ}

Ключовою метою реалізації освіти на сьогодні виступає те, щоб молоде покоління черпало соціальний досвід організації педагогічної праці. А це стане можливим тоді, коли ми виховуватимемо юнацтво з використанням надбань культури попередніх поколінь, яке має в собі певну систему цінностей. Покликання музеїв як культурних 
інституцій сприяє тому, щоб зберігати та досліджувати минувшину, а пріоритетним у цьому буде залучення до цього процесу дітей та юнацтва, бо саме засобами музейної педагогіки у вихованців формується національна свідомість (Самсакова І., 2015, с.120).

Музейна педагогіка - це така галузь діяльності, що покликана передавати культурний досвід і надбання наших предків, а відбувається це за допомогою організації освітнього процесу в музейній установі будь-якого профілю. Головне поняття музейної педагогіки - це музейна культура, яка характеризується підготовленістю учня до сприйняття інформації, а також шанобливе ставлення до історії людства (Шавалда Л., 2014, с. 53). Засоби музейної педагогіки мають на меті розкрити внутрішній світ людини, дати можливість їй побудувати духовні цінності та світосприйняття (Удовиченко І., 2017, с. 15). Особливістю музейної педагогіки є те, що вона не обмежує своє використання в навчальних предметах, тобто їі можливо застосовувати як і в гуманітарних, так і в точних дисциплінах. Використовуючи музейну педагогіку в освітньому процесі, вчителеві (викладачеві) вдається залучити до нього всіх вихованців, що сприяє комунікації один між одним, допомагає комфортно відчувати себе в середовищі, яке $€$ невимушеним та позитивним. Тут особистість має можливість ввійти в роль дослідника, що значно активізує освітній процес (Вайнберг Т., 2014, с. 4).

У світлі нових законів України та Концепції НУШ використання в освітньому процесі засобів музейної педагогіки сприяє реалізації компетентнісного підходу. Проведення занять у музеї допомагає кращому засвоєнню навчального матеріалу не тільки з суспільствознавчих предметів (історія, література тощо), а й приводить до світосприймання особистості (Яковенко Г., 2017, с. 178).

Проаналізуємо можливості музеїв Прикарпаття для реалізації основних компетентностей учня і студента. Музеї писанкової Коломиї (Національний музей народного мистецтва Гуцульщини та Покуття ім. Й. Кобринського, Музей писанкового розпису, Музей історії міста Коломиї) - «культурної столиці» Прикарпаття - виконують не тільки науково-пошукову діяльність, а ще й сприяють вихованню патріотично налаштованої, свідомої генерації молоді, що здійснюється на основі виховання засобами музейної педагогіки, до якої залучаються учні та студенти закладів професійної та вищої освіти.

Співробітники НМНМГП імені Й. Кобринського використовують у роботі різноманітні форми комунікації, пропонують інтерактивні програми та проекти, які відповідають вікові та вподобанням. Застосування інтеракції сприяє розвитку у відвідувачів комунікативних та пізнавальних навичок.

Кожна форма взаємодії, яку застосовують працівники НМНМГП імені Й. Кобринського, реалізує компетентнісний підхід (Ясінська О., 2017, с. 380). Інтерактивні програми допомагають згуртуванню молоді, у ході яких їх об'єднує спільна мета, а також зацікавленість у спільному процесі. По-друге, під час розробки програм та проектів ураховуються вікові особливості, потреби та інтереси особистості. Під час проведення спільних проектів відбувається спілкування між собою, дискусії, що сприяє реалізації мовленнєвої компетенції.

Задля популяризації творів гуцульського мистецтва, а також ознайомлення із життєвим шляхом майстрів у музейній установі створена програма «Музей - школі», яка діє впродовж навчального року, є помічником для вчителя (викладача), який прагне зробити навчання яскравим та незабутнім, а також сприяти тому, щоб зростаюче покоління розуміло цінність народного мистецтва. Програмою проекту передбачено екскурсії, лекції та інтерактивні уроки, майстер-класи та вікторини. Щорічно музей організовує мистецькі заходи, які стосуються народних свят. Під час таких дійств молодь з різних коломийських шкіл, ЗВО мають змогу ознайомитися не тільки з традиційністю цих свят, а й стають активними учасниками майстер-класів (Ясінська О., 2017, с. 380). Щороку на початку березня у НМНМГП імені Й. Кобринського відбуваються заходи, присвячені вшануванню Тараса Шевченка. До таких заходів долучається учнівська та студентська молодь, які знайомляться з мистецькою спадщиною Кобзаря. Молодь декламує вірші Т. Шевченка, ставить інсценізацію із життєвого шляху письменника, до цього процесу також залучаються і батьки. Це допомагає молоді проявити себе, розкрити свої раніше незнані таланти, а також виявляти ініціативу (Ясінська О., 2017, с. 380). У музейній установі відбуваються мистецькі акції «Ніч у музеї». Юнацтво має змогу демонструвати власні творчі здобутки, ставати учасниками вікторин, малювати тощо. Усе це супроводжується активністю та запалом, отриманням сувенірів (Ясінська О., 2017, с. 380). Так реалізується компетенція самовираження. Молодь, залучена у мистецький процес через створення малюнків, має можливість висловити власне «я», що передбачає формування мистецького стилю та смаку.

Ще 2009 р. на базі НМНМГП імені Й. Кобринського працівники музею створили дієву форму взаємодії між музеєм та юнацтвом - «Музейні академії». До цього дійства залучаються учні, студенти, які самостійно обирають питання, що тісно пов'язані з історичними подіями, реаліями сьогодення (Баран Р., Каркадим М., 2015, с. 22). Того ж року Орфеєм, який відкрив «Музейні академії», став проект «Феномен творців фільму «Тіні забутих предків», над якими спільними зусиллями працюють учні із учителями шкіл міста Коломиї, їм допомагають студенти прикарпатських ЗВО. Головною постаттю проекту є український режисер Сергій Параджанов. Учасники готують інформацію про режисера, яка супроводжується мультимедійними презентаціями, проектами (Баран Р., КаркадимК., 2015, с. 23). Таким чином, реалізується інформаційно-цифрова компетентність.

Ще одним вагомим освітньо-виховним осередком міста, який репродукує ідеї музейної педагогіки, є Музей писанкового розпису. У цій «писанковій оазі» $€$ можливість не тільки переглянути експозиційні зали, колекційні зібрання писанок, а й самостійно стати її творцями. 2008 р. на базі музею для молоді засновано Школу писанкарства, де охочі навчаються розписувати писанки, знайомляться із символікою та технологією розпису 
писанок. Завдяки цьому вони вчаться шанобливо ставитися до народного мистецтва, поважати традиції предків. У процесі виготовлення писанок формується образне мислення, власне бачення кольорової гами та індивідуальне оформлення писанок (Блонська І., 2016, с. 46).

Навчання в Школі писанкарства триває 6 місяців (24 год. загального навчання). Звичайно, цей освітній процес дуже цікавий. Його завершальним етапом є захист робіт, який відбувається у передвеликодній період (Блонська І., 2016, с. 47). У процесі виготовлення писанок відбувається спілкування одне з одним, допомога і підтримка творчих починань - реалізація соціальної компетентності. Виготовлення писанок є нелегкою працею, воно вимагає наполегливості, творчості, а також уміння вчитися і вдосконалюватися. У Музеї писанкового розпису це враховують під час проведення уроків у Школі писанкарства. Під час занять з боку народних майстринь та музейних працівників здійснюється орієнтація педагогічних можливостей, спрямованих на потреби тих, хто навчається. За допомогою наочних методів навчання формується образне сприйняття, яке передбачає безпосередній контакт із предметом (наприклад писачком, або ж писанкою). Саме так активізуються тактильні відчуття, які дають змогу дітям та юнацтву відчути форму виробу, з'ясувати, з якого матеріалу цей виріб виготовлений, чи піддається він обробці тощо (Блонська І., 2016, с. 467).

Працівники Музею писанкового розпису сприяють зустрічам з відомими писанкарями краю. Неодноразово гостями-майстрами в «музейній оазі» були Дмитро Пожоджук, Марія Кіращук, Катерина Крилюк (с. Шешори) та ін. Таким чином, відбувається «живе» спілкування, народні майстри діляться своїм досвідом праці, що в майбутньому передбачає збереження молодим поколінням цього неоціненного мистецтва, скарбу нашого краю. Важливо й те, що процес виготовлення писанок $є$ кропіткою роботою, яка вимагає уваги та витривалості.

Доцільним в цьому освітньому процесі постає педагогіка партнерства. 2013 р. у музеї було створено програму «Писанкові фантазії», де відвідувачі мають змогу брати участь у майстер-класах від провідних писанкарів краю. Зацікавленню писанкарством сприяють неодноразові зустрічі з оригінальними людьми, які своєю творчістю надихають молоде покоління, що своєю чергою прищеплює любов до прекрасного, шанобливого ставлення до мистецтва наших предків. Так відбувається зв'язок поколінь, а Музей писанкового розпису сприяє, аби цей зв'язок не було обірвано (Блонська І., 2016, с. 45-46).

Реалізації підприємницької компетенції у зростаючого покоління сприяє проведення благодійних акцій. У Музеї писанкового розпису було організовано акцію «Великодній сувенір». Вона полягала в тому, що учні могли власноруч прикрашати медівники, які мали форму писанки, традиційними писанковими узорами. Після цього вироби було передано бійцям у зону АТО/ООС, які доповнювалися листами. Ця акція дає зрозуміти учням, що праця, яка здійснена на благо ближньому, є запорукою майбутнього кожного, що сприяє вихованню чіткої громадянської позиції у дітей (Блонська I, 2016, с. 46).

Ці заходи організовують небайдужі музейні працівники та вчителі. Вони є надзвичайно важливими. По-перше, юнаки та дівчата не тільки споглядають колекційні писанкові збірки, а стают їхніми авторами, що забезпечує розвиток моторики, пластичності, а також розвиває їхні художні здібності. По-друге, безпосереднє знайомство із майстрами цієї справи посилює зацікавлення дітей займатися писанкарством, сприяє тому, що відбувається зв'язок поколінь, який не дає зникнути цьому давньому і непростому мистецтву. У цьому процесі залучені всі учасники освітнього процесу (учні, вчителі, студенти, викладачі, батьки, музейні працівники). Це сприяє тому, що вчителям вдається організувати освітній процес цікаво і захопливо, тому діти вчаться із задоволенням, пізнають нове для себе, відкривають у собі приховані таланти.

Не можна оминути поза увагою і Музей історії міста Коломиї. Ця музейна установа не тільки зосереджена на науковій та пошуковій діяльності і збереженні музейних експонатів, пов'язаних з історією міста, а й виступає осередком для розвитку та вдосконалення молодого покоління.

Сучасна освіта покликана виховати особистість, яка всебічно розвинена, може застосовувати набуті знання на практиці, уміє шукати інформацію, удосконалюватися і вчитися протягом життя. Перед учителями історії і суспільствознавчих предметів постає широкий вибір форм і методів навчання. Так, екскурсійна робота є актуальною на сьогодні. А скарбницею популяризації цієї ділянки роботи може стати Музей історії міста Коломиї. Це зумовлено двома чинниками. По-перше, якщо використовувати в навчальному процесі екскурсійну діяльність, то можна значно полегшити викладання навчального матеріалу з історії, який можна подати наочним способом та реалізується в ході показу експонатів у музейній установі. По-друге, відбувається урізноманітнення навчання, тобто є можливість залучити молодь до пошукової діяльності. Переліки компетенцій, передбачених у Концепції НУШ, не є обмеженими, вони постають від потреб сучасного світу, бо саме компетентнісний підхід сприяє виробленню в учнів тих навиків та вмінь, які затребувані й актуальні сьогодні, тобто такі, які з легкістю можна реалізувати за допомогою навчальних екскурсій, які поглиблюють знання учнів та роблять навчання невимушеним та цікавим.

Кожного року в Музеї історії міста Коломиї проводять навчальні екскурсії для учнів закладів загальної середньої освіти та студентів ЗВО, які передбачені навчальними планами. За таких умов учитель чи викладач має змогу не тільки глибше ознайомити учнів, студентів з історією рідного міста, а й поєднати його з навчальним матеріалом з вітчизняної історії. Наприклад, тривалий час м Коломия була в підпорядкуванні цісарської Австрії (тобто була частиною Австрійської (з 1867 р. Австро-Угорської) імперії до 1918 р. - авт.), а в музеї містяться експонати, які окреслюють колорит тієї епохи (фото намісників міста, радників магістрату, побутові речі досліджуваного періоду, тощо). На основі цього, використовуючи музейну наочну експозицію, діти можуть засвоїти матеріал про цей період 
історії України, школярі опановують цей матеріал на основі образного мислення. Також молодь має змогу займатися дослідництвом: у приміщенні є бібліотека, яка сприяє пошуку необхідної інформації з історії рідного краю. Таким чином, можливим стає впровадження кейс-технології (case з англ. - випадок, подія). А реалізовується вона таким чином: оптимальною кількістю групи є 3-5 учнів (студентів); на першому етапі молодь отримує проблемне питання, в їхньому арсеналі всі види інформації (у тому числі підказки можна отримати не тільки з музейної експозиції, але й з матеріалів музейної бібліотеки); відбувається добір та опрацювання літератури з певної проблеми; захист відбувається на вибір, з використанням мультимедіа, з постановкою сценки тощо. Також розвиваються такі компетенції: комунікативна (відбувається спілкування, дискутування між учасниками групи); інформаційна (пошук інформації за допомогою різних джерел); навчально-пізнавальна (генерація ідей, рефлексія, самооцінка); соціальна (уміння налагоджувати взаємини з іншими); уміння розв'язувати проблему тощо. Працівники Музею історії м. Коломия сприяють удосконаленню рівня обізнаності молодого покоління шляхом проведення творчих вечорів, виставок молодих художників. Неодноразово в «оазі» історії міста організовуються виступи музичних колективів Коломийської музичної школи № 1. Загалом музей активно співпрацює з дітьми та юнацтвом, сприяє вихованню чіткої громадянської позиції, любові до рідного краю (Арсак, М, 2005, с. 10).

Результати проведеного нами SWAT-аналізу показали, що в контексті реформування сучасної освіти в Україні проблема музейної педагогіки, зокрема функціонування музеїв, є доволі значною (рис.1).

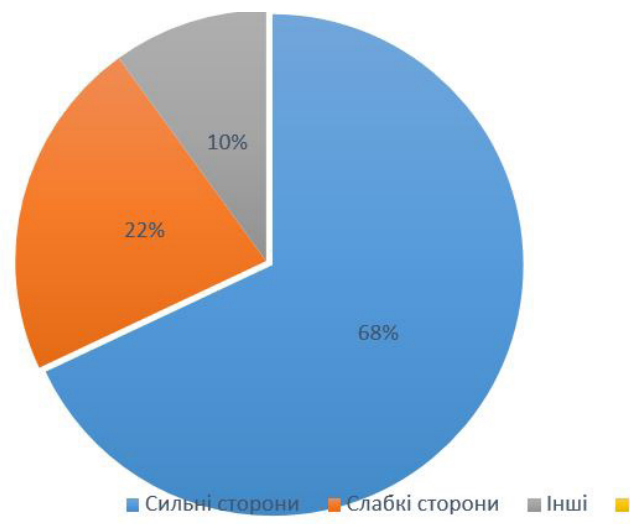

Рис. 1 Результати SWAT-аналізу

Як видно з рис. 1, 68\% респондентів вбачають у впровадженні музейної педагогіки сильні сторони і лише $22 \%$ слабкі сторони.

\section{ВИСНОВКИ ТА ПЕРСПЕКТИВИ ПОДАЛЬШИХ ДОСЛІДЖЕНЬ}

Отже, застосування засобів музейної педагогіки в освітньому процесі $€$ актуальним сьогодні. Музейна педагогіка виступає дієвим засобом для того, щоб виховати свідомих, обізнаних, творчих та активних людей, які в подальшому з легкістю зможуть застосувати на практиці набуті знання, вміння та навички. Майбутній випускник сучасного закладу загальної середньої освіти чи ЗВО повинен володіти системою компетентностей, які дає у тому числі і музейна педагогіка. Саме вчитель, викладач має можливість обрати такі технології роботи, які будуть йому необхідні в організації якісного освітнього процесу. Безперечно, допомогу в цьому надають три головні музеї історії міста Коломиї. Працівники музейних установ, використовуючи елементи музейної педагогіки, сприяють організації цікавої та пізнавальної діяльність у музеях. Перспективи подальших розвідок полягають у вивчення впливу музейної педагогіки інших міст на особистість.

\section{СПИСОК ВИКОРИСТАНИХ ДЖЕРЕЛ}

Арсак, М. (2005). Хроніка Музею історії міста Коломиї 1990-2005. Коломия.

Баран, Р., Каркадим, К. (2015). Музейні академії. Historical and Cultural Studies. 2/1, 19-24.

Блонська, І. (2016) Науково-освітня діяльність Музею писанкового розпису. Сучасний контент. Музейна галузь. Історія, здобутки та перспективи. Матеріали Міжнародної наукової конференції з нагоди 90-річчя заснування Національного музею народного мистецтва Гуцульщини та Покуття імені Й. Кобринського / Наукові редактори Я. Ткачук і А. Королько. Коломия: Вік, 45-48.

Вайнберг, Т. (2014). Музейна педагогіка - продуктивний напрям у сучасній системі національної освіти. Вивчаємо українську мову та літературу. Позакласна робота. Основа, 2, 2-7.

Концепція Нової української школи (2016). Концептуальні засади реформування середньої школи. Ухвалено рішенням МОН, 40.

Самсакова, І. (2015). Виховання особистості учня засобами музейної педагогіки. Педагогічний пошук, 3, 119-123.

Удовиченко, І. (2017). Музейна педагогіка: теорія і практика: науково-методичний посібник. К.: Логос.

Шавалда, Л. (2014). Музейна педагогіка: від традицій співпраці до використання нових педагогічних технологій. Рідна школа. № 12. С. $52-56$

Яковенко, Г. (2017). Методика навчання історії. Навчально-методичний посібник. Харків: ХНАДУ, 324.

Ясінська, О. (2016) Інноваційні форми та інтерактивні програми й проекти для дітей і молоді в Національному музеї народного мистецтва Гуцульщини та Покуття імені Й. Кобринського. Сучасний контент. Музейна галузь. Історія, здобутки та перспективи. 
Матеріали Міжнародної наукової конференції з нагоди 90-річчя заснування Національного музею народного мистецтва Гуцульщини та Покуття імені Й. Кобринського / Наукові редактори Я. Ткачук і А. Королько. Коломия: Вік, 379-383.

\section{REFERENCES}

Arsak, M. (2005). Khronika Muzeju istoriji mista Kolomyji 1990-2005. Kolomyja.

Baran, R., \& Karkadym, K. (2015). Muzejni akademiji. Historical and Cultural Studies. 2/1, 19-24.

Blonsjka, I.(2016) Naukovo-osvitnja dijaljnistj Muzeju pysankovogho rozpysu. Suchasnyj kontent. Muzejna ghaluzj. Istorija, zdobutky ta perspektyvy. Materialy Mizhnarodnoji naukovoji konferenciji z naghody 90-richchja zasnuvannja Nacionaljnogho muzeju narodnogho mystectva Ghuculjshhyny ta Pokuttja im. J. Kobrynsjkogho / Naukovi redaktory Ja. Tkachuk i A. Koroljko. Kolomyja: Vik, 45-48.

Vajnbergh, T. (2014). Muzejna pedaghoghika - produktyvnyj naprjam u suchasnij systemi nacionaljnoji osvity. Vyvchajemo ukrajinsjku movu ta literaturu. Pozaklasna robota. Osnova, 2, 2-7.

Koncepcija Novoji ukrajinsjkoji shkoly (2016). Konceptualjni zasady reformuvannja serednjoji shkoly. Ukhvaleno rishennjam MON.

Samsakova, I. (2015). Vykhovannja osobystosti uchnja zasobamy muzejnoji pedaghoghiky. Pedaghoghichnyj poshuk, 3, 119-123.

Udovychenko, I. (2017). Muzejna pedaghoghika: teorija i praktyka: naukovo-metodychnyj posibnyk. K.: Loghos.

Shavalda, L. (2014). Muzejna pedaghoghika: vid tradycij spivpraci do vykorystannja novykh pedaghoghichnykh tekhnologhij. Ridna shkola. 12. $52-56$.

Jakovenko, Gh. (2017). Metodyka navchannja istoriji. Navchaljno-metodychnyj posibnyk. Kharkiv: KhNADU.

Jasinsjka, O.(2016) Innovacijni formy ta interaktyvni proghramy j proekty dlja ditej i molodi v Nacionaljnomu muzeji narodnogho mystectva Ghuculjshhyny ta Pokuttja imeni J. Kobrynsjkogho. Suchasnyj kontent. Muzejna ghaluzj. Istorija, zdobutky ta perspektyvy. Materialy Mizhnarodnoji naukovoji konferenciji z naghody 90-richchja zasnuvannja Nacionaljnogho muzeju narodnogho mystectva Ghuculjshyny ta Pokuttja imeni J. Kobrynsjkogho / Naukovi redaktory Ja. Tkachuk i A. Koroljko. Kolomyja: Vik, 379-383. 